\title{
IAMJ
}

INTERNATIONAL

AYURVEDIC

MEDICAL JOURNAL

\section{A CLINICAL STUDY TO EVALUATE THE EFFICACY OF KHADIRADI VARTI IN KARNINI YONI VYAPAD WITH SPECIAL REFERENCE TO CERVICAL EROSION}

\author{
Ruksana Parvin'1, Baishya Balen ${ }^{2}$, Humtsoe Yanbeni ${ }^{3}$ \\ ${ }^{1}$ P.G. Scholar, PTSR, ${ }^{2}$ Retd. Professor \& HOD, ${ }^{3}$ Professor and HOD, \\ Department of Prasuti Tantra \& Streeroga, Govt. Ayurvedic College, Ghy-14, Assam, India
}

Corresponding Author: ruksanaparvin1991@gmail.com

\section{https://doi.org/10.46607/iamj0308082020}

(Published online: August 2020)

Open Access

(C) International Ayurvedic Medical Journal, India 2020

Article Received: 10/07/2020 - Peer Reviewed: 29/07/2020 - Accepted for Publication: 01/08/2020

Check for updates

\begin{abstract}
Objectives: Karnini Yoni Vyapad which is one among twenty Yoni Vyapads is a common problem of the females in the reproductive age group. Since the symptoms of Karnini Yoni Vyapad as explained in Samhitas has got similarity with cervical erosion in modern perspective so it has been taken into consideration in this study. This study aimed to assess the efficacy of the trial drug i.e. Khadiradi Varti in the treatment of cervical erosion.

Method: 30 numbers of patients suffering from Karnini Yoni Vyapad (Cervical erosion) were selected from OPD and IPD and were treated with Khadiradi Varti per vaginally following all aseptic measures, once a day preferably at bedtime for 7 consecutive days after completion of menstrual cycle. Such 3 cycles were performed for each patient. Result: The trail drug have efficacy in reducing severity of signs and symptoms like degree of cervical erosion (Yoni Karnika), cervical odema (Yoni Soth), discharge per vagina (Yoni Srava), bleed on touch (Rakta Srava) associated with Karnini Yoni Yyapad without having any toxicity or adverse effect on the body.
\end{abstract}

Keywords: Karnini Yoni Vyapad, Cervical erosion, Khadiradi Varti. 
Karnini Yoni Vyapad ${ }^{1,2,3,4,5,6,7}$ which is one among twenty Yoni Vyapads is a common problem of the females in the reproductive age group. Cervical ero$\operatorname{sion}^{8,9}$ is a common condition seen in most women of all the age groups. The understanding of cervical erosion in Ayurveda is equivocal. As the symptoms of Karnini Yoni Vyapad as explained in Samhitas has got similarity with cervical erosion in modern perspective so it has been taken into consideration in this study. The treatment protocols for Karnini Yoni Vyapad is based on correction of Vata Dosa which is the root cause all the Yoni Vyapads. The formulation selected for the present study is Khadiradi Varti ${ }^{10}$ which corrects Vata-Vaigunya in general and ApanavayuVaigunya as well as Kapha Dosha which is the main Dosha involved in the pathogenesis of the disease. This study aimed at systematic compilation, analysis and interpretation of the concepts of Karnini Yoni Vypad with the contemporary science, understanding the concepts of cervical erosion from an Ayurvedic perspective and to assess the efficacy of the trial drug i.e. Khadiradi Varti in the treatment of it.

Materials and Methods: In this present study an open randomized clinical trial of Khadiradi Varti has been carried out to evaluate its efficacy in Karnini Yoni Vyapad (Cervical erosion),

Source of Data: 35 numbers of patients suffering from Karnini Yoni Vyapad (Cervical erosion) are selected from OPD and IPD of Govt. Ayurvedic Hospital, Dept. of Prasuti Tanta and Stree Roga,

Selection Criteria: A group of 35 patients having signs and symptoms of Karnini Yoni Vyapad will be selected and will be treated with Khadiradi Varti per vagina following all aseptic measures, once a day preferably at bedtime for 7 consecutive days after completion of menstrual cycle.

\section{Inclusion Criteria:}

- Women having signs and symptoms of Karnini Yoni Vyapad (cervical erosion).

- Married female patients between age group 18-44 years

\section{Exclusion Criteria:}

- Pregnant lady

- HIV, HBsAg, STD, Fungal infection, Malignancy, DUB, AUB

- Diabetes Mellitus, Tuberculosis, Severe liver disease, renal disease.

- Symptoms associated with underling pelvic pathology like Fibroid uterus, ovarian cyst, PID.

\section{Investigations:}

- TC, DLC, ESR, Hb\%, RBS, HIV, HBsAg, HCV, VDRL

- Vaginal Ph, swab culture, PAP Smear

- USG (to know pelvic pathology)

- Urine hCG (in patient with h/o amenorrhea)

Trial Methodology: The study was performed in a randomized open trial.

Preparation Of The Trial Drug Khadiradi Varti: The used parts of ingredients are Khadir (heart wood), Haritaki (fruit), Jatiphala (fruit), Nimba (stem bark), Puga (tender nut). The Varti is manufactured at State Ayurvedic Pharmacy, Government Ayurvedic College, Guwahati, Assam.

Method of Preparation: All the ingredients were collected locally and sundried for a day then in their dry form these were washed thoroughly with clean tap water and then dried in machine dryer and finely powdered separately. Then equal parts of powdered form of all the five ingredients i.e. Khadir, Haritaki, Jatiphala, Nimba and Puga are mixed well in the ratio of 1:1:1:1:1 and given Bhavana of distilled water. Then under all aseptic and antiseptic precaution manually Vartis are prepared of $5 \mathrm{~g}$ each, in oviform shape resembling that of Pradeshini Anguli Pramana ${ }^{11}$. The final drug was again vacuum dried and subjected to UV radiation. Packaging done for prepared formulation in sterile poly-bags with zip lock where single packet of drug contains 7 numbers of Vartis. These were kept in cool and dry place to avoid disintegration and contamination. The preparation is done in Rasashala of Govt. Ayurvedic College and Hospital. The Varti was tested in State Drug Testing Laboratory (AYUSH), Guwahati for physical and biochemical assay. 
Dose and Duration of Treatment: The prepared formulation is given in the dose of 1 Varti per vaginally daily at bedtime was carried out for 7 days in each cycle after the cessation of menstruation. Such 3 cycles will be performed for each patient.

Follow Up: Assessment of the parameters will be done after each cycle on $15^{\text {th }}$ days of application of the drug for 3 consecutive cycles in the same manner.

\section{Assessment Parameters:}

- Degree of cervical erosion (Yoni Karnika)

- Cervical odema (Yoni Sotha)

- Discharge per vagina (Yoni Srava)

- Lower abdominal pain (Udara Shula)

- Low backache (Kati Shula)

- Bleeding on touch (Rakta Srava)

Results: In this present study, total 35 numbers of patients were given treatment initially. But during the course of treatment 5 patients were dropped out who are excluded from statistical analysis. Out of these 5 patients, 3 patients got pregnant after starting of treatment and 2 patients discontinued the treatment. Total 30 numbers of patients were given complete treatments along with follow up of three consecutive cycles.

\section{Clinical Review:}

\section{A. Pre-Observations:}

Degree of Cervical Erosion: In the study, it is found that out of 30 patients, 15 patients i.e. 50\% had Erosion on the upper /lower cervical lip. 9 numbers of patients i.e. $30 \%$ had sign of Erosion involving both upper and lower lips, 6 numbers of patients i.e. $20 \%$ Erosion involving the whole cervix, $0 \%$ patients had no erosion.
Cervical Oedema: Out of 30 patients, $36.67 \%$ patients have the symptoms of oedema involving both upper and lower lips, $33.33 \%$ patients have the symptom of Oedema involving the whole cervix, $20 \%$ patients have the symptom of Oedema on the upper /lower cervical lip, 10\% patients have no oedema,

Discharge Per Vagina: Out of 30 patients, $56.67 \%$ patients have the symptoms of Wetting of undergarments present as stated by patient and on $\mathrm{P} / \mathrm{S}$ examination discharge positive, $26.67 \%$ patients have the symptom of Occasional discharge, $16.67 \% \%$ patients have the symptom of Excessive vaginal discharge as stated by patients and out pouring discharge during $\mathrm{P} / \mathrm{S}$ examination, $0.0 \%$ patients have no complain of discharge.,

Lower Abdominal Pain: Out of 30 patients, $76.67 \%$ patients have the symptoms of No pain, $23.33 \%$ patients have the symptom of Occasional, no interference with daily routine, $0 \%$ patients have the symptom interference with daily routine, $0 \%$ patients have severe tenderness during P/A examination.,

Low Backache: Out of 30 patients, $83.33 \%$ patients have the symptoms of No pain, $16.67 \%$ patients have the symptom of Occasional, no interference with daily routine, $0 \%$ patients have the symptom of Backache, interference with daily routine, and $0 \%$ patients have excessive symptoms.,

Bleeding on Touch: Out of 30 patients, $80 \%$ patients have the symptoms of No bleeding, $10 \%$ patients have the symptom of Bleeding on rubbing with swabs, $6.67 \%$ patients have the symptom of Bleeding on slight touch, and $3.33 \%$ patients have bleeding only on compression.

\section{B. Statistical Review:}

1. Effect of trial drug on Degree of cervical erosion on $1^{\text {st }}$ follow up, $2^{\text {nd }}$ follow up and $3^{\text {rd }}$ follow up ( $\left.N=30\right)$

\begin{tabular}{|l|l|l|l|l|l|l|l|l|l|l|}
\hline $\begin{array}{l}\text { Follow up 15 days after each cycle of } \\
\text { treatment }\end{array}$ & $\overline{\mathrm{X}}_{\mathrm{BT}}$ & $\overline{\mathrm{X}}_{\mathrm{AT}}$ & $\overline{\mathrm{X}}_{\mathrm{BT}}-\overline{\mathrm{X}}_{\mathrm{AT}}$ & $\mathrm{SD}_{\mathrm{BT}}$ & $\mathrm{SD}_{\mathrm{AT}}$ & $\mathrm{SE}$ & $\mathrm{t}_{29}$ & $\mathrm{P}$ & Remarks \\
\hline $1^{\text {st }}$ follow up & 1.70 & 1.03 & 0.67 & 0.79 & 0.89 & 0.088 & 7.61 & $<0.0001$ & H.S \\
\hline $2^{\text {nd }}$ follow up & 1.70 & 0.53 & 1.17 & 0.79 & $\mathrm{O}$ & & & & & \\
\hline After treatment & 1.70 & 0.37 & 1.33 & 0.79 & 0.61 & 0.111 & 12.02 & $<0.0001$ & H.S \\
\hline
\end{tabular}


2. Effect of trial drug on Cervical Oedema on $1^{\text {st }}$ follow up, $2^{\text {nd }}$ follow up and $3^{\text {rd }}$ follow up $(\mathrm{N}=27)$

\begin{tabular}{|l|l|l|l|l|l|l|l|l|l|l|}
\hline $\begin{array}{l}\text { Follow up 15 days after each cycle of } \\
\text { treatment }\end{array}$ & $\overline{\mathrm{X}}_{\mathrm{BT}}$ & $\overline{\mathrm{X}}_{\mathrm{AT}}$ & $\overline{\mathrm{X}}_{\mathrm{BT}}-\overline{\mathrm{X}}_{\mathrm{AT}}$ & $\mathrm{SD}_{\mathrm{BT}}$ & $\mathrm{SD}_{\mathrm{AT}}$ & $\mathrm{SE}$ & $\mathrm{t}_{26}$ & $\mathrm{P}$ & Remarks \\
\hline $1^{\text {st }}$ follow up & 2.15 & 0.89 & 1.26 & 0.77 & 0.97 & 0.156 & 8.04 & $<0.0001$ & H.S \\
\hline $2^{\text {nd }}$ follow up & 2.15 & 0.44 & 1.71 & 0.77 & 0.64 & 0.129 & 13.23 & $<0.0001$ & H.S \\
\hline After treatment & 2.15 & 0.41 & 1.74 & 0.77 & 0.64 & 0.137 & 12.70 & $<0.0001$ & H.S \\
\hline
\end{tabular}

3. Effect of trial drug on Discharge per vagina on $1^{\text {st }}$ follow up, $2^{\text {nd }}$ follow up and $3^{\text {rd }}$ follow up $(N=30)$

\begin{tabular}{|l|l|l|l|l|l|l|l|l|l|l|}
\hline $\begin{array}{l}\text { Follow up 15 days after each cycle of } \\
\text { treatment }\end{array}$ & $\overline{\mathrm{X}}_{\mathrm{BT}}$ & $\overline{\mathrm{X}}_{\mathrm{AT}}$ & $\overline{\mathrm{X}}_{\mathrm{BT}}-\overline{\mathrm{X}}_{\mathrm{AT}}$ & $\mathrm{SD}_{\mathrm{BT}}$ & $\mathrm{SD}_{\mathrm{AT}}$ & $\mathrm{SE}$ & $\mathrm{t}_{29}$ & $\mathrm{P}$ & Remarks \\
\hline $1^{\text {st }}$ follow up & 1.90 & 1.00 & 0.90 & 0.66 & 0.91 & 0.11 & 8.115 & $<0.0001$ & H.S \\
\hline $2^{\text {nd }}$ follow up & 1.90 & 0.60 & 1.30 & 0.66 & 0.62 & 0.08 & 15.276 & $<0.0001$ & H.S \\
\hline After treatment & 1.90 & 0.40 & 1.50 & 0.66 & 0.56 & 0.10 & 14.354 & $<0.0001$ & H.S \\
\hline
\end{tabular}

4. Effect of trial drug on Lower abdominal pain on $1^{\text {st }}$ follow up, $2^{\text {nd }}$ follow up and $3^{\text {rd }}$ follow up (N=7)

\begin{tabular}{|l|l|l|l|l|l|l|l|l|l|}
\hline $\begin{array}{l}\text { Follow up 15 days after each cycle of } \\
\text { treatment }\end{array}$ & $\overline{\mathrm{X}}_{\mathrm{BT}}$ & $\overline{\mathrm{X}}_{\mathrm{AT}}$ & $\overline{\mathrm{X}}_{\mathrm{BT}}-\overline{\mathrm{X}}_{\mathrm{AT}}$ & $\mathrm{SD}_{\mathrm{BT}}$ & $\mathrm{SD}_{\mathrm{AT}}$ & $\mathrm{SE}$ & $\mathrm{t}_{6}$ & $\mathrm{P}$ & Remarks \\
\hline $1^{\text {st }}$ follow up & 1.00 & 0.86 & 0.14 & 0.00 & 0.38 & 0.143 & 1.00 & $<0.359$ & N.S \\
\hline $2^{\text {nd }}$ follow up & 1.00 & $\mathrm{O} .57$ & 0.43 & 0.00 & 0.53 & 0.202 & 2.12 & $<0.078$ & N.S \\
\hline After treatment & 1.00 & 0.57 & 0.43 & 0.00 & 0.53 & 0.202 & 2.12 & $<0.078$ & N.S \\
\hline
\end{tabular}

5. Effect of trial drug on Low Backache on $1^{\text {st }}$ follow up, $2^{\text {nd }}$ follow up and $3^{\text {rd }}$ follow up $(\mathrm{N}=5)$

\begin{tabular}{|l|l|l|l|l|l|l|l|l|l|}
\hline Follow up 15 days after each cycle of treatment & $\overline{\mathrm{X}}_{\mathrm{BT}}$ & $\overline{\mathrm{X}}_{\mathrm{AT}}$ & $\overline{\mathrm{X}}_{\mathrm{BT}}--\overline{\mathrm{X}}_{\mathrm{AT}}$ & $\mathrm{SD}_{\mathrm{BT}}$ & $\mathrm{SD}_{\mathrm{AT}}$ & $\mathrm{SE}$ & $\mathrm{t}_{4}$ & $\mathrm{P}$ & Remarks \\
\hline $1^{\text {st }}$ follow up & 1.00 & 0.80 & 0.20 & 0.00 & 0.45 & 0.20 & 1.00 & $<0.373$ & N.S \\
\hline $2^{\text {nd }}$ follow up & 1.00 & 0.80 & 0.20 & 0.00 & 0.45 & 0.20 & 1.00 & $<0.373$ & N.S \\
\hline After treatment & 1.00 & 0.80 & 0.20 & 0.00 & 0.45 & 0.20 & 1.00 & $<0.373$ & N.S \\
\hline
\end{tabular}

6. Effect of trial drug on Bleeding on touch on $1^{\text {st }}$ follow up, $2^{\text {nd }}$ follow up and $3^{\text {rd }}$ follow up $(\mathrm{N}=6)$

\begin{tabular}{|l|l|l|l|l|l|l|l|l|l|l|}
\hline $\begin{array}{l}\text { Follow up 15 days after each cycle of } \\
\text { treatment }\end{array}$ & $\overline{\mathrm{X}}_{\mathrm{BT}}$ & $\overline{\mathrm{X}}_{\mathrm{AT}}$ & $\overline{\mathrm{X}}_{\mathrm{BT}}-\overline{\mathrm{X}}_{\mathrm{AT}}$ & $\mathrm{SD}_{\mathrm{BT}}$ & $\mathrm{SD}_{\mathrm{AT}}$ & $\mathrm{SE}$ & $\mathrm{t}_{5}$ & $\mathrm{P}$ & Remarks \\
\hline $1^{\text {st }}$ follow up & 2.17 & 0.67 & 1.50 & 0.75 & 0.82 & 0.224 & 6.708 & $<0.001$ & $\mathrm{~S}$ \\
\hline $2^{\text {nd }}$ follow up & 2.17 & 0.17 & 2 & 0.75 & 0.41 & 0.258 & 7.746 & $<0.006$ & H.S \\
\hline After treatment & 2.17 & 0.17 & 2 & 0.75 & 0.41 & 0.258 & 7.746 & $<0.006$ & H.S \\
\hline
\end{tabular}

7. Final assessment of the trial drug on all signs and symptoms of cervical erosion:

\begin{tabular}{|c|c|c|c|c|c|c|c|c|c|c|}
\hline \multirow[t]{3}{*}{ Symptoms } & \multirow{2}{*}{\multicolumn{2}{|c|}{$\begin{array}{l}\text { Before treatment } \\
\text { Cured }\end{array}$}} & \multicolumn{8}{|c|}{ After treatment } \\
\hline & & & \multicolumn{2}{|c|}{$\begin{array}{l}\text { Moderate } \mathrm{Im}- \\
\text { provement }\end{array}$} & \multicolumn{2}{|c|}{$\begin{array}{l}\text { Mild Improve- } \\
\text { ment }\end{array}$} & \multicolumn{2}{|c|}{ Unchanged } & \multicolumn{2}{|l|}{ Cured } \\
\hline & $\begin{array}{l}\text { No. of } \\
\text { Patients }\end{array}$ & $\%$ & $\begin{array}{l}\text { No. of } \\
\text { Patients }\end{array}$ & $\%$ & $\begin{array}{l}\text { No. of } \\
\text { Patients }\end{array}$ & $\%$ & $\begin{array}{l}\text { No. of } \\
\text { Patients }\end{array}$ & $\%$ & $\begin{array}{l}\text { No. of } \\
\text { Patients }\end{array}$ & $\%$ \\
\hline Cervical erosion & 30 & 100 & 21 & 70 & 7 & 23.33 & 2 & 6.67 & 0 & 00 \\
\hline Cervical oedema & 27 & 100 & 18 & 66.67 & 7 & 25.92 & 2 & 7.40 & 0 & 00 \\
\hline Discharge per vagina & 30 & 100 & 19 & 63.33 & 10 & 33.33 & 1 & 3.33 & 0 & 00 \\
\hline Lower abdominal pain & 7 & 100 & 3 & 42.86 & 0 & 00 & 0 & 00 & 4 & 57.14 \\
\hline Low backache & 5 & 100 & 1 & 20 & 0 & 00 & 0 & 00 & 4 & 80 \\
\hline Bleed on touch & 6 & 100 & 5 & 83.33 & 1 & 16.67 & 0 & 00 & 0 & 00 \\
\hline
\end{tabular}


After completion of the study, the statistical evaluation showed that clinically out of 30 patients, 30 patients had Cervical erosion, 27 patients had symptoms of cervical oedema, patients had symptoms of discharge per vagina, 7 patient had symptoms of lower abdominal pain, 5 patients had low backache, 6 patients had bleeding on touch.

Cervical erosion Clinically out of 30 total patients, all the 30 patients had the symptom. After the treatment 21 patients i.e. $70 \%$ had complete cure, 7 patients i.e. $23.33 \%$ patients had moderate improvement, 2 patients i.e. $6.67 \%$ had mild improvement. No patients remained unchanged.

Cervical oedema, Clinically, out of 30 total patients, all the 27 patients had the symptom. After the treatment 18 patients i.e. $66.67 \%$ had complete cure, 7 patients i.e. $25.92 \%$ patients had moderate improvement and 2 patients i.e. $7.40 \%$ shows mild improvement. No patient remained unchanged.

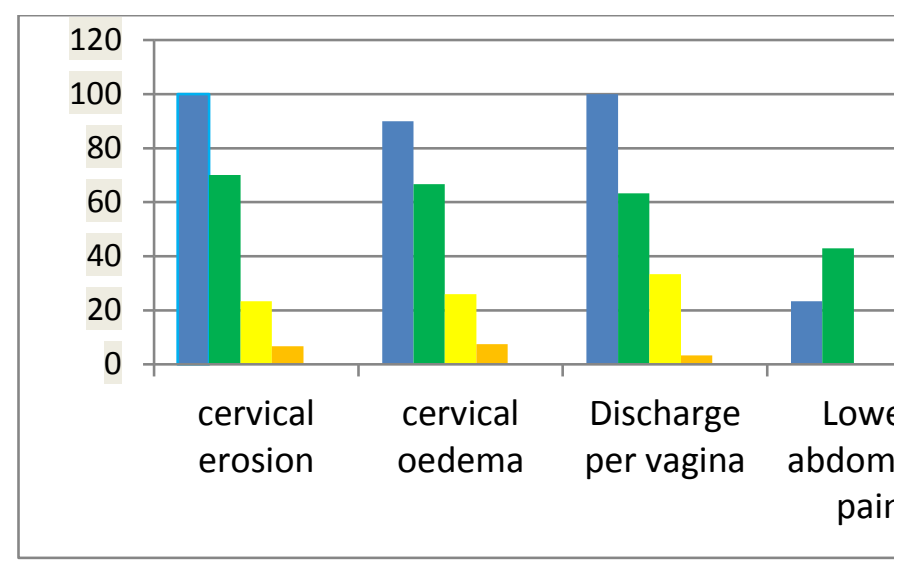

Photos of cervical erosion:

A. Before

\section{B. After treatment}

Discharge per vagina, clinically out of 30 patients, all the 30 patients had the symptom. After treatment 19 patients i.e. $63.33 \%$ had complete cure, 10 patients i.e. $33.33 \%$ had moderate improvement, 1 patient i.e. $3.33 \%$ had mild improvement. No patient remained unchanged.

Lower abdominal pain: Clinically 7 patients out of 30 had the symptom. After treatment 3 patients i.e. $42.86 \%$ showed complete cure and rest 4 patients i.e. $57.14 \%$ showed no improvement.

Low backache: Clinically out of 30 total patients, 5 patients had the symptom. After the treatment only 1 patient i.e. $20 \%$ showed complete cure, rest 4 patients i.e. $80 \%$ showed no improvement.

Bleed on touch: Clinically out of 30 total patients, 6 patients had the symptom. After the treatment 5 patient i.e. $83.33 \%$ showed complete cure, 1 patient i.e. $16.67 \%$ showed no improvement.

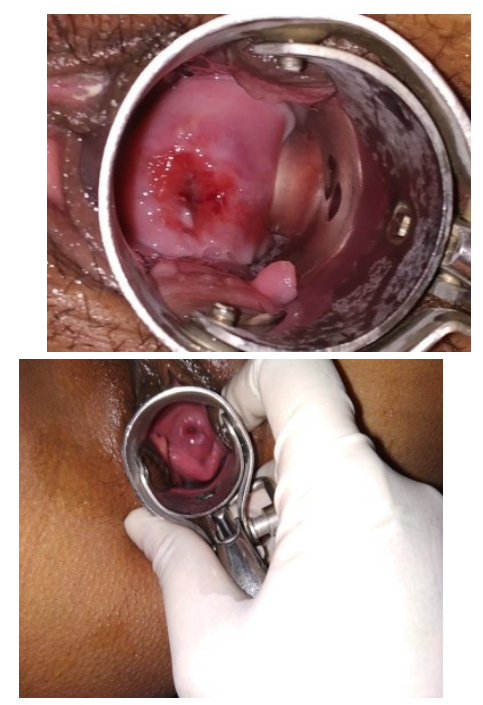

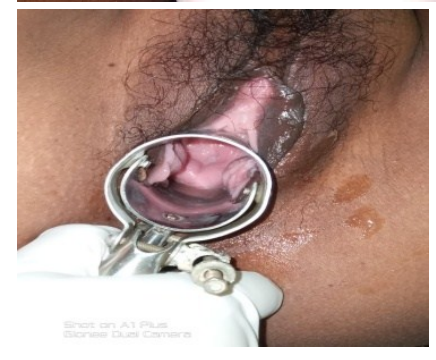

i. Cervical erosion iii. Discharge per vagina

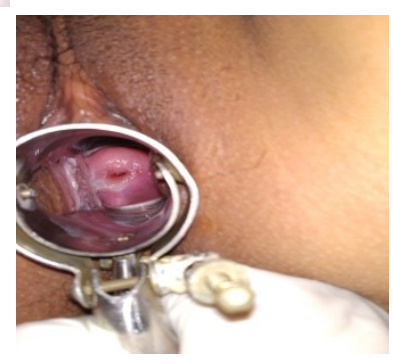

ii. Cervical oedema iv. Normal cervix 


\section{DISCUSSION}

The probable mode of action of the trial drug in concerned parameters are-

Decrease in surface area of erosion (Yoni Karnika) due to Kasaya, Tikta and Katu Rasa, Laghu and Ruksha Guna and Stambhana, Vranapachana, Vranasodhana, Vranaropana, Raktasodhan Karma, Decrease Yoni Srava due to Kasaya, Tikta and Katu Rasa, Laghu and Ruksha Guna; Ushna Virya and Stambhana, Grahi, Kledanasana Karma, Decrease in Yoni Sotha due to Tikta and Kasaya Rasa and Sothahara Karma, Decrease in Kati and Udara Shula due to Usna Virya and Vata Hara Karma. In modern parameters these effects can be inferred due to antiinflammatory, immunomodulatory, antibacterial, astringent, anti-hemorrhagic properties of the ingredients of Khadiradi Varti, thereby cause rapid reepithelization and healing of cervical erosion, reduce cervical oedema, discharge per vagina and bleed on touch of cervix.

Discussion on the observation of demographic profile: Age: In the trial it was found that maximum patients $46.67 \%$ are from age group of $27-35$ years, followed by $33.33 \%$ belonging to age group $18-26$ years which support the prevalence of the disease during this active reproductive period in population with principle estrogenic action. Only $20 \%$ patients were from age group 36-44years, indicating less active reproductive life and decline in estrogenic effect.

Menstrual cycle (interval): This study shows that 21 patients i.e. $70 \%$ have regular menstrual cycle and 9 patients i.e. $30 \%$ have irregular menstrual cycle. This may not have any relationship with Karnini Yoni Yapad so no comments can be made due to a smaller number of observations i.e. 30 .

Menstrual cycle (flow): This study shows that 21 patients i.e. $70 \%$ have average menstrual flow; 5 patients i.e. $16.67 \%$ have excessive menstrual flow and 4 patients i.e. $13.33 \%$ have scanty menstrual flow. This also may not have any relationship with Karnini Yoni Vyapad. So, no comments can be made due to a smaller number of observations.

Parity: Among 30 patients it is evident from the data that maximum 13 patients i.e. $43.34 \%$ have 1 child while 9 patients i.e. $30 \%$ have 2 children. 5 patients i.e. $16.67 \%$ have 3 children while 2 patients i.e. $6.67 \%$ have 0 children and 1 patient i.e. $3.33 \%$ has 4 children. Though it is evident that parity have direct influence on the causation of cervical erosion and increase in parity should increase the incidence of disease, but such observation is not found in the present study which may be due to less numbers of subjects i.e. 30 .

Abortion history: In this study shows 22 patients i.e. $73.34 \%$ have no Abortion history and 8 patients i.e. $26.67 \%$ have Abortion history. No conclusion could be made whether abortion (either induced or spontaneous) had direct effect on cervical erosion. Though some literature says abortion influence the cervical erosion.

\section{Discussion on the clinical results:}

In respect of cervical erosion, it was observed that 30 patients had cervical erosion. The drug is found highly significant after three follow up of treatment, after 15 days of each cycle of treatment, i.e. $t_{29}=12.02, p$ $<0.0001$. Hence the effect of the trial drug is highly significant. In respect of cervical oedema, it was observed that 27 patients had cervical oedema. The drug is found highly significant after three follow up of treatment, after 15 days of each cycle of treatment, i.e. $\mathrm{t}_{26}=, 12.70, \mathrm{p}<0.0001$. Hence the effect of the trial drug is highly significant. In respect of Discharge per vagina, it was observed that 30 patients had Discharge per vagina. The drug is found highly significant after three follow up of treatment, after 15 days of each cycle of treatment, i.e. $t_{29}=14.353, p<0.0001$. Hence the effect of the trial drug is highly significant. In respect of Lower abdominal pain, it was observed that 7 patients had Lower abdominal pain. The drug is found not significant after three follow up of treatment, after 15 days of each cycle of treatment, i.e. $t_{6}=2.12, p$ $<0.078$. Hence the effect of the trial drug is not significant. In respect of Low Backache, it was observed that 5 patients had Low Backache. The drug is found not significant after three follow up of treatment, after 15 days of each cycle of treatment, i.e. $t_{4}=1.00, p$ $<0.373$, hence the effect of the trial drug is not significant. In respect of Bleeding on touch, it was observed that 6 patients had Bleeding on touch. The drug is 
found highly significant after three follow up of treatment, after 15 days of each cycle of treatment, i.e. $\mathrm{t}_{5}=6.708, \mathrm{p}<0.006$, Hence the effect of the trial drug is highly significant.

\section{CONCLUSION}

The trail drug Khadiradi Varti have efficacy in reducing severity of signs and symptoms like degree of cervical erosion (Yoni Karnika), cervical odema (Yoni Soth), discharge per vagina (Yoni Srava), bleed on touch (Rakta Srava) associated with Karnini Yoni Vyapad without having any toxicity or adverse effect on the body. The study revealed that the drug Khadiradi Varti at the dose 1 Varti per vaginally for 7 consecutive days in a month after completion of menstruation cycle for 3 such cycles is effective statistically in the reduction of all clinical features accept the associated symptoms of pain in lower abdomen (Udara Shula) and low backache (Kati Shula) of the Vyadhi Karnini Yoni Vyapad. This may be a pioneer study and a ready reference for the future research scholars. Further studies on larger sample with assessment of biochemical, cellular and experimental parameters are needed for more precise conclusion on the drug in order to establish its efficacy in Karnini Yoni Vyapad (Cervical Erosion).

\section{REFERENCES}

1. Dwibedi Dr. Laximidhar, Edited by Dwibedi Dr. B.K. And Goswami Dr. Pradeep Kumar, Chraka Samhita, $2^{\text {nd }}$ Edition, Varanasi, Chaukhambha Bharati Academy,2016, Chikitsasthana 30/27-28, P-191

2. Dwibedi Dr. Laximidhar, Edited by Dwibedi Dr. B.K. And Goswami Dr. Pradeep Kumar, Chraka Samhita, $2^{\text {nd }}$ Edition, Varanasi, Chaukhambha Bharati Academy, 2016, Chikitsasthana 30/27-28, Chakrapani P-191

3. Thakral Dr. Keval Krishna, Sushruta Samhita, Varanasi, Chaukhambha Orientalia, 2017, Uttara Sthana 38/15,17 P- 215.

4. Thakral Dr. Keval Krishna, Sushruta Samhita, Varanasi, Chaukhambha Orientalia, 2017, Uttara Sthana 38/15, 17, Dalhan, P- 215.

5. Tripathi Dr. Brahmananda, Astanga Hridaya, Delhi, Chaukhamba Sanskrit Pratisthan, 2014, Uttara Sthana 33/50-51. P 1133

6. Sastri Sri Sudarsana, Edited By Upadhyaya Vaidya Yadunandana, Madhava Nidan, Varanasi, Chaukhambha Prakashan, 2013, Chapter 62/8,10, P- 425
7. Sastri Vaidya Sri Lakshmipati, Edited By Sastri Sri Brahmasankar, Yoga Ratnakar, $2^{\text {nd }}$ Edition, Varanasi, Chaukhamba Sanskrit Sansthan, 2002, Yonirogadhikar 12, P-406

8. Dutta D. C. Edited by Konar Hiralal The Textbook Of Gynaecology, $5^{\text {th }}$ Edition, Kolkata. New Central Book Agency (P) LTD; 2008. P.257

9. Howkins And Bourne, Edited By VG Padubidri, Shaw's Textbook Of Gynaecology, $16^{\text {th }}$ Edition,2017, P171

10. Pandey Sri Hariprasad Edited By Sastri Brahma Sankar, Bhabaprakash, Varanasi. Chaukhambha Sanskrit Series Office, 1998, Chikistasthana Yonirogadhikar 70/48, P-801

11. Dwibedi Dr. Laximidhar, Edited By Dwibedi Dr. B.K. And Goswami Dr. Pradeep Kumar, Chraka Samhita, $2^{\text {nd }}$ Edition, Varanasi, Chaukhambha Bharati Academy, 2016, Chikitsasthana 30/72, P-999

\section{Source of Support: Nil \\ Conflict of Interest: None Declared}

How to cite this URL: Ruksana Parvin et al: A Clinical Study To Evaluate The Efficacy Of Khadiradi Varti In Karnini Yoni Vyapad With Special Reference To Cervical Erosion. International Ayurvedic Medical Journal \{online\} 2020 \{cited August, 2020\} Available from: http://www.iamj.in/posts/images/upload/4043 4049.pdf 